\title{
Biostimulation combined treatments for remediation of diesel contaminated soil
}

\author{
C. Calvo ${ }^{1}$, G. A. Silva-Castro ${ }^{1}$, I. Uad ${ }^{1}$, M. Manzanera ${ }^{1}$, \\ C. Perucha ${ }^{2}$, J. Laguna ${ }^{2} \&$ J. Gónzalez-López ${ }^{1}$ \\ ${ }^{I}$ Department of Microbiology, Institute of Water Research, \\ University of Granada, Spain \\ ${ }^{2} A G$ Ambiental, Spain
}

\begin{abstract}
Bioremediation is an important technology for the restoration of oil polluted environments by indigenous or selected microorganisms. In general, the rate of biodegradation depends on the number and types of microorganisms, the nature and chemical structure of pollutants to be degraded and the environmental conditions. In this study we have evaluated the efficacy of the application of four different biostimulation treatments for the biodegradation of diesel contaminated soils. The treatments applied involved: (a) the addition of NPK fertilizer + Ivey I surfactant; (b) the addition of NPK fertilizer + Ethanol; (c) the addition of NPK fertilizer + Biorem; and (d) oxidation by Fenton's reagent combined with NPK fertilizer. Microbial activity was evaluated following growth of heterotrophic and degrading microorganisms, dehydrogenase activity and $\mathrm{CO}_{2}$ production. Hydrocarbons degradation was established by determination of TPH, alkanes, branched alkanes, pristane and phytane by GC/MS. Our results have shown that the application of NPK fertilizer in combination with Ivey surfactant is an efficient treatment to be applied in clay soil. Treatment with Fenton's reagent previous to the application of NPK fertilizer also efficiently enhanced hydrocarbon biodegradation in saturated conditions.
\end{abstract}

Keywords: bioremediation, hydrocarbon pollution, surfactant, Fenton reagent.

\section{Introduction}

Bioremediation offers a more environmentally friendly alternative by taking advantage of the oil degrading microorganisms and by establishing and 
maintaining the physical, chemical and biological conditions that favour enhanced oil biodegradation rates in the polluted environment [1]. Biological processes have been used successfully to remediate soils polluted with petroleum hydrocarbons and their derivatives [2]. It is considered an environmentally acceptable way of eliminating oils and fuel because the majority of hydrocarbons in crude oils and refined products are biodegradable, and hydrocarbons degrading microbes are ubiquitous [3]. One of the best approaches to restore polluted soils consists in using microorganisms able to degrade those toxic compounds for bioremediation processes [4].

Biostimulation process introduces additional nutrients into a polluted system to increase indigenous microorganisms. Contamination of a zone with hydrocarbons originates a rapid depletion of the available pools of major inorganic nutrients, such as $\mathrm{N}$ and $\mathrm{P}$. Consequently, nutrient supplementation for hydrocarbons degradation has been traditionally focused on addition of nitrogen and phosphorous either in the organic or inorganic forms [5].

Besides adding nutrients to accelerate the breakdown of oil by microorganisms, another factor that enhances oil biodegradation consists in enlarging oil dispersion addition of either by chemical or biological surfactants. In general, microbial attack takes place at the oil-water interface, thus enhanced biodegradation should results as a consequence of the increasing surface area available for microbial colonization [6].

Emulsifiers can emulsify hydrocarbons by enhancing their water solubility and increasing the displacement of oily substances from soil particles [7]. For these reasons, inclusion of surfactants in a bioremediation treatment of a hydrocarbon polluted environment could be of great advantage. In consequence, addition of surfactant and other natural emulsifying agents are important tools for biotreatment of hydrocarbon polluted environment [8].

On the other hand, bioremediation is often limited to those compounds that are biodegradable, and not all compounds are susceptible to rapid and complete degradation [9], for this reason, application of combined processes based on combination between oxidation and biological treatment have been used for the removal of some pollutants present in soil. Among the different available oxidants, hydrogen peroxide and Fenton's reagent have been widely and successfully applied for the remediation of many organic compounds [10]. Fenton reaction causes the dissociation of the oxidant and the formation of highly reactive hydroxyl radicals. The unstable hydroxyl radicals formed are used to degrade organic compounds either by hydrogen abstraction or by hydroxyl addition [11]. This reaction increases availability source of carbon to microorganisms in biological treatment. They can also be combined with bioremediation to design complete soil treatment processes [12].

Biological degradation represents one of the major routes through which hydrocarbons can be removed from polluted environments. To show the potential bioremediation technology, it is important use of to enhance the rate of hydrocarbon biodegradation under controlled conditions. The laboratory feasibility study involves microbiological and chemical methods to measure the effectiveness of bioremediation under predetermined conditions. 
In this study, laboratory microcosms were carried out to measure the changes in microbial activities and hydrocarbons biodegradation during bioremediation treatment. The aim of this research was to understand the extent of oil hydrocarbon degradation under different experimental treatments combining inoculation with NPK fertilizer and Ivey surfactant, Biorem, ethanol as biostimulating agents and pre-treatment with Fenton reagent as oxidant agent.

\section{Materials and methods}

\subsection{Soil samples}

In this study we used was loam clay soil polluted at the origin and supplied by AG Ambiental S.L. This soil was composed of 36\% clay, 33\% sand, 1.67 COT, $577 \mathrm{mg} / \mathrm{kg}$ Nitrogen, 299mg/kg Phosphorus and $28135 \mathrm{mg} / \mathrm{kg}$ Iron.

\subsection{Biostimulating agents}

NPK inorganic fertilizer (18:8:17 Agroblem SA) was composed of $18 \%$ total Nitrogen; $8 \%$ Phosphorus pentoxide $\left(\mathrm{P}_{2} \mathrm{O}_{5}\right) ; 17 \%$ Potassium oxide $\left(\mathrm{K}_{2} \mathrm{O}\right) ; 2 \%$ Magnesium oxide (MgO) and 19\% Sulphur trioxide (SO3). Ivey-sol ${ }^{\mathbb{R}}$ Surfactant comprised of several patented and preparatory non-ionic surfactant formulations.

Biorem combination is an organic fertilizer composed of $31.5 \%$ COT, $3 \%$ Nitrogen, $0.06 \%$ Phosphorus and $1 \%$ Potassium. Ethanol is classified as a primary alcohol, a group of chemical compounds whose molecules contain a hydroxyl group, bonded to a carbon atom.

\subsection{Oxidation agents}

Fenton's reagent is a mixture of $\mathrm{H}_{2} \mathrm{O}_{2}$ and ferrous iron, which generates hydroxyl radicals. The factors more important in Fenton process are the relationship between Oxidant agent $\left(\mathrm{H}_{2} \mathrm{O}_{2}\right)$ and Organic compounds $(\mathrm{RH})$ and the $\mathrm{pH}$. The optimum $\mathrm{pH}$ is around 3 .

\subsection{Microcosm assays}

Microcosms were built in $500 \mathrm{ml}$ Erlenmeyer flask, each flask containing $250 \mathrm{~g}$ of soil. Experiments were prepared with the NPK fertilizers as the principal biostimulation agent, supplemented or not with other biostimulation additive i.e. Ivey surfactant, Biorem, ethanol and Fenton's reagent [11].

All supplemented additives were applied at two different concentrations and set up at room temperature. Treatments are detailed in table 1 .

\subsection{Enumeration of culturable bacteria in soil}

Three replicate samples from each microcosm treatment were withdrawn every week for enumeration of aerobic heterotrophic bacteria and degrading bacteria. $0.1 \mathrm{ml}$ of serially diluted soil samples were plated on 1/10 diluted Trypticase Soy 
Table 1: $\quad$ Experimental design.

\begin{tabular}{||c||c|c|c|c|c|c||}
\hline \hline & Treatment & NPK fertilizer & $\begin{array}{c}\text { Ivey } \\
\text { Surfact }\end{array}$ & Biorem & Ethanol & Fenton \\
\hline \hline A & $\begin{array}{c}\text { Natural } \\
\text { attenuation }\end{array}$ & - & - & - & - & - \\
\hline B & NPK & $\begin{array}{c}0.3 \mathrm{~g} / \mathrm{kg} \text { of } \\
\text { soil }\end{array}$ & - & - & - & - \\
\hline C & $\begin{array}{c}\text { NPK + Ivey } \\
\text { Surfactant }\end{array}$ & $\begin{array}{c}0.3 \mathrm{~g} / \mathrm{kg} \text { of } \\
\text { soil }\end{array}$ & $52 \mu \mathrm{l} / \mathrm{Kg}$ & - & - & - \\
\hline $\mathrm{D}$ & $\begin{array}{c}\mathrm{NPK}+ \\
\text { Biorem }\end{array}$ & $\begin{array}{c}0.3 \mathrm{~g} / \mathrm{kg} \text { of } \\
\text { soil }\end{array}$ & - & $5 \mathrm{~g} / \mathrm{kg}$ & - & - \\
\hline $\mathrm{E}$ & $\begin{array}{c}\mathrm{NPK}+ \\
\text { Ethanol }\end{array}$ & $\begin{array}{c}0.3 \mathrm{~g} / \mathrm{kg} \text { of } \\
\text { soil }\end{array}$ & - & - & $0.2 \% \mathrm{w} / \mathrm{w}$ & - \\
\hline F & $\begin{array}{c}{\left[\mathrm{H}_{2} \mathrm{O}_{2}\right], \mathrm{Fe}{ }^{+3}+} \\
\mathrm{NPK}\end{array}$ & $\begin{array}{c}0.3 \mathrm{~g} / \mathrm{kg} \text { of } \\
\text { soil }\end{array}$ & - & - & - & $11.5 \mathrm{ml}$ \\
\hline
\end{tabular}

Agar (TSA, Difco). Degrading bacteria were counted on $1 \%$ hydrocarbon trypticase soy agar. Triplicate plates were incubated at $28^{\circ} \mathrm{C}$ for $48 \mathrm{~h}$ before the colonies were counted.

\subsection{Biological activity}

Dehydrogenase activity was determined by the reduction 2,3,5tryphenylterazolium chloride (TTC) to tryphenyl formazan (TPF) according [13].

Production of $\mathrm{CO}_{2}$ was determined by gas chromatography (Varian Star 3400 cx, with TCD Detector). Soil samples for the respiration test, were incubated in a closed vessel at $28^{\circ} \mathrm{C}$ [14].

\subsection{Hydrocarbon analysis}

Total petroleum hydrocarbons were determined using EPA 8015 (GROs + DROs) [15]. The gasoline range organics (GROs) were introduced into the GC/FID by purge and-trap, automated headspace, and the Diesel range organics (DROs) were prepared by soxhlet extraction .

Analysis of each hydrocarbon fraction were performed from the extracted fractions above mentioned using a Hewlett-Packard 6890 GC system equipped with a HP-5-MS-capillary column $(30 \mathrm{~m} \times 0.32 \mathrm{~mm}$ I.D. Fraction of hydrocarbons were detected using a mass detector 5872 (Hewlett-Packard) and a library utilized was Wiley 275.

\subsection{Statistical analyses}

Mean, variance and standard deviation of the microbiological and chemical parameters were calculated from the values obtained in each measurement of the triplicate samples. Differences between biological and chemical analysis in the different soil samples were tested by student test. The statistical significance was evaluated at the $\mathrm{P}<0.05$. All statistical analyses were carried out using the SPSS 15.0 software. 


\section{Results and discussion}

Microcosm test can be used to assess the biodegradation potential of hydrocarbons. Screening of bioremediation treatments can be used to design the most appropriate bioremediation strategy for large scale application. In this study, we have compared the effect of various bioremediation treatments on hydrocarbon removal. Strong correlation between microbial counts and hydrocarbons degradation has been reported by Al-Awadhi et al. [16]. The results obtained in this study have shown that Surfactant (C) and Fenton (F) treatments increased the number of both heterotrophic and hydrocarbon degrading bacteria (figure 1). In addition, the number of bacteria detected at the beginning of treatment (near $10^{7}$ ) was upper than those usually counted in non polluted soil, indicating that polluted samples studied have been enriched in hydrocarbon tolerant microorganisms. These results could be explained by an adaptation of microbiological population to the pollutants. Also, none of the nutrients added inhibit microbial growth, indicating that no toxic effect was observed on microbial populations.
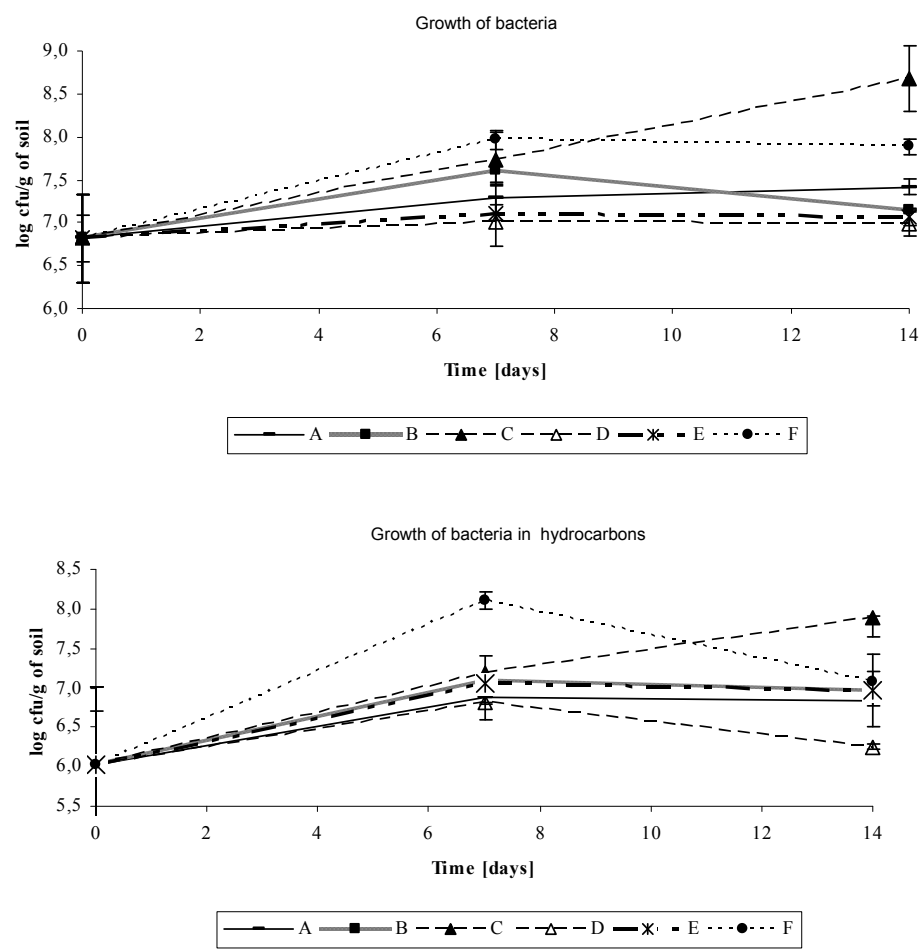

Figure 1: Number of total heterotrophic and degrading bacteria during treatment. 
Dehydrogenase activity measured in soil has been used to monitor activity as an index for the total oxidative activity of microorganisms. In general, biological oxidation of organic compounds is generally a dehydrogenation process, which is catalyzed by dehydrogenase enzymes [17]. Table 2 shows data of biological activity obtained at the beginning and end of soil treatment. We observed high dehydrogenase activity at the beginning of treatment B, C with $429.7 \mathrm{TPF} / \mathrm{g}$, and 411.1 TPF/g respectively. High values of dehydrogenase activity were correlated with stimulation of microbial populations measured at the end of the experiments.

Soil respiration is another measure of the total biological activity and result of degradation of organic matter (Table 2). Production of $\mathrm{CO}_{2}$ decreased after 14 days of treatment, and only treatment $\mathrm{D}$ produced an increase in $\mathrm{CO}_{2}$ production of $0.04 \%$ from $0.27 \% \quad(p<0.05)$. These parameters showed a significant biological activity in these soil samples polluted at source meaning that microbial populations were already adapted to oil hydrocarbons pollution.

Table 2: Microbial activity estimated by moisture, dehydrogenase and production of $\mathrm{CO}_{2}$.

\begin{tabular}{|c||c|c||c|c||c|c||}
\hline \multirow{2}{*}{ Treat } & \multicolumn{2}{c|}{ Moisture } & \multicolumn{2}{c||}{ Dehydrogenase } & \multicolumn{2}{c||}{ \%CO $_{\mathbf{2}} \mathbf{2 4 h}$} \\
\cline { 2 - 7 } & $\mathbf{t}_{\mathbf{0} \text { days }}$ & $\mathbf{t}_{\mathbf{1 4} \text { days }}$ & $\mathbf{t}_{\mathbf{0} \text { days }}$ & $\mathbf{t}_{\mathbf{1 4} \text { days }}$ & $\mathbf{t}_{\mathbf{0} \text { days }}$ & $\mathbf{t}_{\mathbf{1 4} \text { days }}$ \\
\hline \hline $\mathrm{A}$ & $24,8 \pm 0,0$ & $24,4 \pm 0,1$ & $90,0 \pm 12,2$ & $69,4 \pm 4,7$ & $0,14 \pm 0,01$ & $0,16 \pm 0,03$ \\
\hline $\mathrm{B}$ & $25,9 \pm 1,0$ & $19,0 \pm 1,7$ & $429,7 \pm 112,5$ & $301,1 \pm 45,8$ & $0,38 \pm 0,04$ & $0,21 \pm 0,03^{\mathrm{a}}$ \\
\hline $\mathrm{C}$ & $34,2 \pm 0,8$ & $33,5 \pm 1,0$ & $411,1 \pm 131,3$ & $371,5 \pm 37,1$ & $0,35 \pm 0,05$ & $0,17 \pm 0,03^{\mathrm{a}}$ \\
\hline $\mathrm{D}$ & $28,2 \pm 0,6$ & $27,8 \pm 0,1$ & $13,6 \pm 0,4$ & $74,8 \pm 21,3^{\mathrm{a}}$ & $0,04 \pm 0.00$ & $0,21 \pm 0,04^{\mathrm{a}}$ \\
\hline $\mathrm{E}$ & $29,8 \pm 0,1$ & $24,6 \pm 2,2$ & $21,9 \pm 0,3$ & $69,4 \pm 13,3^{\mathrm{a}}$ & $0,19 \pm 0,01$ & $0,19 \pm 0,02$ \\
\hline $\mathrm{F}$ & $34,6 \pm 0,5$ & $38,4 \pm 2,6$ & $106,9 \pm 30,83$ & $120,3 \pm 7,92$ & $0,18 \pm 0,0$ & $0,16 \pm 0,0$ \\
\hline $\boldsymbol{P}^{\boldsymbol{a}}$ & $*$ & $*$ & $*$ & $*$ & $*$ & $*$ \\
\hline
\end{tabular}

$\boldsymbol{P}^{a}$ from one-way ANOVA, $* * *, * *, *<0.001,0.01,0.5$, respectively.

Labels (a) Indicates statistically significant between $\mathrm{t}=0$ days and $\mathrm{T}=14$ days, using t-student; $\mathrm{P}<0.05$.

Chromatographic analysis was used to estimate the degradation of TPH, nalkanes, branched alkanes, pristine and phytane as biomarkers. The effect of the bioremediation treatments on the degradation of hydrocarbon fractions is shown in Table 3. When comparing bioremediation treatments with natural attenuation, all treatments showed better rate of degradation in all fractions. However, its efficacy varied with the hydrocarbons fractions to be considered, thus for TPH removal, treatment $\mathrm{B}(\mathrm{NPK})$ was the most efficient $(87.6 \%)$; but treatment $\mathrm{C}$ (NPK + surfactant) improved the removal of alkanes (94.1\%). Finally, treatment with Fenton reagent achieved $100 \%$ of Pristane degradation.

Biological processes have traditionally been considered incompatible with chemical oxidation because of excessive death and inactivation of the native microorganisms [18]. However, Fenton's reaction may be recommended as a pre-treatment bioremediation process, because oxidation process reduces TPH, 
Pristane and phytane. That oxidation does not affect microbial number and chemical and biological oxidation of contaminants in soil and can proceed simultaneously with treatment remediation. Mater et al. [19] suggested that the Fenton's reagent increased degradation of hydrocarbons in water bodies and wastewaters showing high efficiency when conditions are optimized.

In summary, treatability studies indicate that addition of nutrients and surfactants increase the rate of hydrocarbons biodegradation in soil. However, our results showed that addition of inorganic fertilizers after a pre-treatment with Fenton's reagent could be efficient treatment in the bioremediation of oilcontaminated soil, in particular in soils where the microbiological populations are adapted to the pollutants.

Table 3: Percentages and correlation indices of degradation in soil after biostimulating treatment.

\begin{tabular}{|c|c|c|c|c|c|c|c|c|c|c|}
\hline \multirow[b]{2}{*}{ Treat } & \multicolumn{2}{|c|}{ TPH } & \multicolumn{2}{|c|}{ Alkanes } & \multicolumn{2}{|c|}{$\begin{array}{c}\text { Branched } \\
\text { alkanes }\end{array}$} & \multicolumn{2}{|c|}{ Pristane } & \multicolumn{2}{|c|}{ Phytane } \\
\hline & $\%$ & Ic & $\%$ & Ic & $\%$ & Ic & $\%$ & Ic & $\%$ & Ic \\
\hline A & $\begin{array}{c}19,6 \pm \\
0,21\end{array}$ & 1 & $\begin{array}{c}25,9 \pm 0 \\
20\end{array}$ & 1 & $39,9 \pm 0,16$ & 1 & $\begin{array}{c}39,6 \pm 0,1 \\
6\end{array}$ & 1 & $40,0 \pm 0,16$ & 1 \\
\hline B & $\begin{array}{c}87,6 \pm \\
0,55\end{array}$ & 4,5 & $\begin{array}{c}87,8 \pm 0 \\
54\end{array}$ & 4,5 & $88,9 \pm 0,66$ & 4,5 & $\begin{array}{c}92,1 \pm 0,9 \\
7\end{array}$ & 4,7 & $91,4 \pm 1,05$ & 4,6 \\
\hline $\mathrm{C}$ & $\begin{array}{c}80,9 \pm \\
3,78\end{array}$ & 4,1 & $\begin{array}{c}94,1 \pm 1 \\
14\end{array}$ & 4,8 & $72,9 \pm 5,20$ & 3,7 & $\begin{array}{c}72,7 \pm 5,2 \\
3\end{array}$ & 3,7 & $73,7 \pm 5,06$ & 3,7 \\
\hline $\mathrm{D}$ & $\begin{array}{c}54,6 \pm \\
0,22\end{array}$ & 2,8 & $\begin{array}{c}67,1 \pm 0 \\
16\end{array}$ & 3,4 & $56,5 \pm 0,21$ & 2,8 & $\begin{array}{c}60,1 \pm 0,1 \\
9 \\
\end{array}$ & 3,1 & $62,1 \pm 0,18$ & 3,2 \\
\hline$E$ & $\begin{array}{c}70,3 \pm \\
0,35\end{array}$ & 3,6 & $\begin{array}{c}74,2 \pm 0 \\
30\end{array}$ & 3,8 & $75,9 \pm 0,28$ & 3,8 & $\begin{array}{c}77,9 \pm 0,2 \\
5\end{array}$ & 3,9 & $78,4 \pm 0,25$ & 3,9 \\
\hline$F$ & $\begin{array}{c}70,1 \pm \\
1,29 \\
\end{array}$ & 3,6 & $\begin{array}{c}25,8 \pm 0 \\
44\end{array}$ & 1,3 & $48,0 \pm 5,95$ & 2,4 & $\begin{array}{c}100,0 \pm 0 \\
00\end{array}$ & 5,1 & $70,5 \pm 0,18$ & 3,6 \\
\hline$P^{a}$ & \multicolumn{2}{|c|}{$* * *$} & \multicolumn{2}{|l|}{$* * *$} & \multicolumn{2}{|l|}{$* * *$} & \multicolumn{2}{|l|}{ *** } & \multicolumn{2}{|l|}{$* * *$} \\
\hline
\end{tabular}

$\boldsymbol{P}^{a}$ from one-way ANOVA, $* * *, * *, *<0.001,0.01,0.5$, respectively.

Ic: Correlation indices of degradation were calculated by the following expression: [\% of degradation treatment $/ \%$ of degradation Control].

\section{Acknowledgement}

This research has been supported by projects of Ministerio de Medio Ambiente (MMA. A4872007/20-01.1).

\section{References}

[1] Zhu, X., Venosa, A.D., Suidan, M.T., Lee, K., 2001. Guidelines for the bioremediation of Marine Shorelines and Freshwater Wetlands. Us Environmental Protection Agency. 
[2] Mulligan, C.N., Yong and R.N., Gibbs B.F. 2001. Surfactant-enhanced remediation of contaminated soil: a review. Engineering Geology, 60, 371380 .

[3] Kanaly, R.A., Harayama, S. (2000). Biodegradation of high-molecularweight polycyclic aromatic hydrocarbons by bacteria. Journal Bacteriology, 182, 2059-2067.

[4] Bento, F.M., Camargo, F., Okeke B., Frankenberger W. 2005.Comparative bioremediation of soils contaminated with diesel oil by natural attenuation, biostimulation and bioaugmentation. Bioresource Technology 96: 10491055 .

[5] Sarkar, D., Ferguson, M., Datta, R., Birnbaum, S. 2005. Bioremediation of petroleum hydrocarbons in contaminated soil: Comparison, and monitored natural attenuation. Environmental Pollution 136, 187-195.

[6] Nikolopoulou, N., Kalogerakis, N., 2008. Enhanced bioremediation of crude oil utilizing lipophilic fertilizers combined with biosurfactants and molasses. Marine Pollution Bulletin, 56; 1855-1861

[7] Banat, R.S., Makkar, S.S., Cameotra. 2000. Potential commercial applications of microbial; surfactants, Applied Microbiology Biotechnology. 53: 495-508.

[8] Ron and E. Rosenberg. 2002. Biosurfactants and oil bioremediation, Curr. Opin. Biotechnol. 13, 249-252.

[9] Vidali. M. 2001. Bioremediation. An overview. Pure Appll. Chem., 73, 1163-1172

[10] Ferrarse, E., Andreottola, G. 2008. Application of advanced oxidation processes and electroxidation for the remediation of river sediments contaminated by PAHs. Journal of Environmental Science and Health Part A. $43,1361-1372$.

[11] Gan, S., Lau, E.V., Ng, N.K. 2009. Remediation of soil contaminated with polycyclic aromatic hydrocarbons (PAHs). Journal of Hazardous Materials. $172,532-549$.

[12] Valderrama, C., Alessandri, R., Aunola, T., Cortina, J.L., Gamisans, X., Tuhkanen, T. 2009. Oxidation by Fenton's reagent with biological treatment applied to a creosote-contaminated soil. Journal of Hazardous Materials. 166, 594-602.

[13] Tabatabai, M.A. (1982). Soil Enzymes. In: Page, A.L., Miller, R.H., Keeney, D.R. (Eds), Methods of Soil Analysis: Part 2. Chemical and Microbiological Properties. (pp 903-943) American Society of Agronomy, Soil Science Society of America, Madison, Wisconsin USA

[14] Bremner, M.J., Blackmer, A.M. (1982). Composition of Soil Atmospheres. In: Page, A.L., Miller, R.H., Keeney, D.R. (Eds), Methods of Soil Analysis: Part 2. Chemical and Microbiological Properties. (pp 903-943) American Society of Agronomy, Soil Science Society of America, Madison, Wisconsin USA.

[15] US Environmental Protection Agency, 1996.Hazardous waste- test Methods, Nonhalogenated organics by GAS Chromatography. 8015. 
[16] Al-Awadhi, N., Al-Daher, R., El-Nawawy, A., Balba, M.T. 1996. Bioremediation of oil-contaminated soil in Kuwait I. Landfarming to remediate oil-contaminated soil. Journal of Soil Contamination, 5; 243-260.

[17] Paul, E.A., Clark, F.E., 1989. Soil Microbiology and Biochemistry, Academic Press, New York, 46-48.

[18] Ndjou'ou, A., Cassidy, D. 2006. Surfactant production accompanying the modified Fenton Oxidation of hydrocarbons in soil. Chemosphere 65, 16101615.

[19] Mater, L., Rosa, E.V.C., Berto, A.X.R., Corrêa, Schiwingel, P.R., Radetski, C.M. 2007. A simple methodology to evaluate influence of $\mathrm{H} 2 \mathrm{O} 2$ and $\mathrm{Fe} 2+$ concentrations on the mineralization and biodegradability of organic compounds in water and soil contaminated with petroleum. Journal of Hazardous Materials 149, 379-386. 